\title{
Houses and economy in the favela
}

Eugênia Motta

\section{Abstract}

A particular house provides the thread for a description of how people manage their domestic spaces, plan for the future, earn and spend money and care for their family. The aim of the article is to reflect on the elements that modulate the economy of the favela where they live, setting out from the notion of house, taken as a complex array of people, objects and spaces constructed in relation to other houses. These relations involve interdependence, asymmetries, affects and conflicts visible through everyday exchanges, commensality and the use of money. The ethnographic approach allows us to take economic practices as a window onto the ways in which the many dimensions of social life are intertwined: economy, family practices, gender relations, morality, spatiality and temporality. The text aims to engage in a critical dialogue with views of the favela as a place of absence and of the economy as a separate sphere of life.

Keywords: economy; favela; Complexo do Alemão; house

\section{Resumo}

Uma casa em particular é fio condutor para a descrição de como as pessoas gerem as suas casas, planejam o futuro, ganham e gastam dinheiro e cuidam de suas famílias. Trata-se de refletir a partir daí sobre os elementos que modulam a economia da favela onde vivem a partir da noção de casa, tomada como um arranjo complexo de pessoas, objetos e espaços construídos e que se constitui em relação a outras. Estas relações envolvem interdependência, assimetrias, afetos e conflitos visíveis por meio das trocas cotidianas, da comensalidade e do uso do dinheiro. A abordagem etnográfica permite tomar as práticas econômicas como uma janela a partir da qual é possível reconhecer como diversas dimensões da vida social estão entrelaçadas: economia, 
práticas familiares, relações de gênero, moralidades, temporalidades e espacialidades. Pretende-se dialogar criticamente com visões da favela como lugar de ausência e da economia como esfera separada da vida.

Palavras-chave: economia; favela; Complexo do Alemão; casa 


\section{Houses and economy in the favela'}

Eugênia Motta

Aliança ${ }^{2}$ is one of the favelas forming an area known as Complexo do Alemão, in Rio de Janeiro, Brazil. Maria and Antônio have lived there for more than thirty years. They came from other states: Maria from a bordering state and Antônio from one in the northeast. A number of their relatives also live in this favela, including their two daughters with their respective husbands and children. Since going to live in Complexo do Alemão they have lived in a series of houses and earned money in a variety of ways. Antônio worked in various factories and today is a concierge. Maria used to be a cleaner and has sold food on the beach and in the street. The two also used to run their own snack bar. Maria today splits her time between her home and her social project, a rented place a few dozen metres away, where she organizes several activities for children of the community to, in her words, keep them off the street where they could get into bad company. The following view of life in the favela sets out from the life of this couple and their house.

Situated in the North Zone of Rio de Janeiro city, the first occupation of what is today known as Complexo do Alemão dates from the start of the twentieth century (IPEA 2013). The area forms part of the so-called Leopoldina Suburb, referring to the branch of the railway line around which the districts of Ramos, Inhaúma, Olaria and Bonsucesso developed. Today only the names survive of most of the many factories once located in this region. These names - 'Coca-Cola,' 'Poesi' (a lingerie factory) and 'Castrol' - serve as local reference points for residents and visitors to Complexo do Alemão, though the factories themselves have vanished.

\footnotetext{
1 I wish to thank all the colleagues and friends who have commented on earlier versions of this text: Andrés Góngora, Flavia Dalmaso, Pedro Braum and Joseph Handerson. I am especially grateful for the important contributions from Federico Neiburg, Fernando Rabossi, Louis Marcelin, Gustavo Onto and Benoît de L’Estoile. I also thank all my colleagues in Rio and Paris who patiently listened to and commented on presentations of this work.

2 The names of the location and the people cited in this paper are fictitious.
} 
Along with Complexo da Penha, Complexo do Alemão forms a continuous area of occupation extending across a sizeable part of the Misericórdia ridge. Many residents disagree vehemently with the official data produced by the 2010 Population Census by the IBGE (Brazilian Institute of Geography and Statistics) which registered 60,583 people living in 18,442 households. The number of favelas or communities ${ }^{3}$ making up Complexo varies according to the source, but the residents divide the region into fourteen main localities: Morro Alemão, Pedra do Sapo, Grota, Canitar, Alvorada, Palmeiras, Nova Brasília, Fazendinha, Casinhas, Relicário, Morro dos Mineiros, Matinha, Morro do Adeus and Morro da Baiana.

The Aliança community extends from a large, busy avenue to the top of a hill. Paved two-way streets cross the favela, used by motorcycle taxis, vans and trucks. But the roads are not the only spaces people use to move about. Alleys, steps and passageways criss-cross apparently randomly in every direction. People use these to circulate on foot or sometimes by motorbike. Some of the few open spaces contain courtyards and small squares. A number of these were built as part of the urban interventions recently implemented in Complexo. 4

Some houses in Aliança have two or three floors and tiled walls. Others lack plaster, leaving their structure exposed. At the top of the hill are houses made from wood, very often containing a single room and frequently without a bathroom. In the geography of the favela, the higher up the location, the cheaper the house and the poorer the people living there are presumed to be. The precarious condition of the sanitation and water supply is one of the factors differentiating this zone, along with the greater distance from the transportation routes that provide access to other areas of the city.

Over time one learns that a door on the street may lead inside a house but also into corridors, or sometimes a series of corridors leading to several houses. There are also vilas, closed-off groups of houses whose gates impede connection to public areas of circulation - the streets or alleyways. This internal geography is invisible from a distance, meaning that from a bird's

3 Both words are used by dwellers to refer to the place where they live. The use of one or the other is situational and depends on who is the interlocutor and the topic, with 'community' being the more commonly used in everyday conversation.

4 Primarily through the works linked to the Federal Government's Growth Acceleration Program (PAC: Programa de Aceleração do Crescimento), executed in the region since 2007. 
eye view there often appears to be no space to walk between the constructions. An outsider may easily get lost.

Many shops, beauty parlours, workshops and snack bars line Aliança's streets. All kinds of clothing can be bought, as well as beauty products, groceries, construction materials and mobile phones, while almost anything can be brought to be repaired. The alleys also contain bars and small shops, and posters can often be seen on the house doors announcing small clothing repairs or food for sale.

The roads are fairly busy, especially those used by vans and motorbikes. At school opening and closing times they fill with children in school uniform, and at the end of the afternoon with men and women, many of them also in uniform, climbing up the hill, arriving from work, or walking down to the churches found scattered throughout the favela. Officers from the Pacification Police Unit are also always visible in the main street, the amount of firearms on display and the position of the cars varying from day-to-day.

Spanning from large houses to shacks, broad paved roads to narrow alleys, large supermarkets to tiny stores, Aliança is a place of enormous diversity. These differences are perceived more clearly the closer one is to the everyday life of local people.

Following the suggestion of Federico Neiburg (2014), in this text I look to show some of the "elements that modulate the economy" of Aliança through an analysis focusing on one house - that of Maria and Antônio - and other houses interrelated through theirs. I describe various forms of earning, spending, keeping and loaning money, and how various objects circulate, in order to comprehend how people manage their houses on a day-to-day basis, care for their families and plan for the future. The ethnographic approach enables the observed economic practices to become a window onto family practices, forms of thinking and building material spaces - to limit ourselves to the main questions to be explored here. This involves a shift, therefore, from the question of 'whether' morality, affects and kinship, for example, are involved in economic practices to an attempt to comprehend 'how' they combine in the shaping of a social world.

In the first part of the text I briefly present a discussion of the ideas of 'house' and 'configuration of houses' as analytic strategies that afford a positive perspective of the economy and the favela. Just as the house allowed kinship and family studies - in which the concept gained strength - to 
examine relationalities and processes (rather than structures, models and functions), it also enabled the construction of a perspective that opposes the normativities typically present in outside views of the favela and definitions of 'the' economy. The material house, from this viewpoint, is one of the elements in a complex arrangement of relations that also includes people and objects. This arrangement and their elements are mutually constituted in the circulations and transformations - in motion.

Next I shall describe two forms through which new houses were made: the house of Maria and her daughters, and the house of one of her nephews. The tie of origin between the houses places them in a relation that is maintained over time and involves mutual obligations and moralities. Ideas of autonomy lie at the base of the house's genesis and are strongly linked to the relation of care between those connected to it. As an autonomous space, the house is founded on the interdependence expressed in the asymmetry between those who care and those who are cared for.

After this I shall show, based on the everyday exchanges related to food, how the configuration of houses is constituted. Observation of how meals are organized and prepared, and how the objects surrounding meals circulate, reveals that the houses are related to each other in different ways and that these relations only become intelligible when relations internal to the house are considered simultaneously. The kitchen is a central place in these relations and the basis for the expression of a particular order between people in a configuration of houses, which differentiates men and women, adults and children. Observing the control over planning, preparing and consuming meals by a woman and other processes involved in the management of the food, it is possible to perceive the hierarchies, relations of proximity and affect displayed in the acts of cooking and eating.

The 'house money' provides the basis for understanding the forms through which earnings and expenditures are managed. The expression eloquently points to the centrality of the house and defines obligations and prohibitions in relation to its maintenance, in the strong sense of the word, including its integration with other houses. Still in relation to money, I shall call attention to specific circuits that are formed through the perceived identity between objects or between forms of earning and spending money, highlighting those circuits that are distinctively female. Notions such as 'domestic budget" and 'family income,' used in government statistics and 
public policy planning, are thrown into question. In the construction of public numbers (Porter 1995), domiciles and families not only comprise discrete objects, their isolation is also the basis for the organization of statistical data. Management of the house, as far as the use of money reveals, is not organized through calculations of global incomings and outgoings, nor based on the house as a closed unit.

Finally I shall discuss a central aspect of the houses in Aliança: the mutability of the constructed spaces. The transformative possibilities of the constructions are allied to the combination of different activities in which people engage to earn money, whether at the same time or over their lifetime. I shall show, particularly in relation to women who are mothers, how the possibility of constructing a business space is combined with perceived risks to their children. Parents commonly fear that their children, especially boys at the beginning of adolescence, may become involved in activities linked to the illicit drugs trade or those perceived to be linked to them, like stealing. People usually refer to these perceived threats as the possibility of youngsters "getting to do something wrong" or getting involved with "bandits."

Another form of earning money is linked to the possibility of possessing or multiplying constructions (with the division of a house or shop into two, for example) - namely renting out properties, considered a 'sure' source of money. The dividing up of spaces enables the multiplication of earnings and activities, central to the strategies of Aliança's residents.

Based on questions linked to mutability of spaces, I shall briefly raise some points concerning the regulations for using and transmitting constructions by selling or leasing. The interpretative framework of 'informality' proves fallible in terms of making these relations intelligible, connected as they are to multiple kinds of regulations and legalities, state laws and technologies among them.

Another aspect of the mutability of the constructions concerns the past, imagined and supposed transformations that compose a repertoire for speaking about the past and future, evaluating good and bad business deals, and building reputations. The constructions are the basis for a kind of temporality that eschews the divisions of the calendar. In the narratives on the past, births and deaths (the events rather than the dates) merge with the houses and their transformations to become temporal landmarks, just as when people talk about their plans through imagined transformations to the buildings. 
The viewpoint from the houses in Aliança is pre-eminently female. Women are at the centre of houses and of the relations between them. Annette Weiner (1992) has shown how the observation of women's practices and viewpoints challenges some explanatory models. For the author, female subordination is shown to be an implicit premise that obscures the complexity of actual exchanges and power relations. Following Weiner's arguments, the female perspective adopted in my own approach aims to provide a more intelligible account of this social world in which women are the main agents in managing the house, care and day-to-day exchanges. As Janet Carsten (1995) suggests, women here are not linked to the house in opposition to a supposed 'public' space, but through everyday practices that form the basis of the everyday economy of Aliança.

\section{Houses and configurations of houses}

An examination of houses can be found throughout much of the anthropological tradition. In Brazil the classic studies of social transformation in the Northeast showed the central role of the house in comprehending social relations in rural areas, including questions linked to work and the economy (Heredia 1979, Garcia 1975, Palmeira 1977). Kinship studies, however, is where the idea of the house assumes a much greater centrality and density, the landmark being Lévi-Strauss's proposal concerning the 'societé de maison' (Lévi-Strauss 1991).

According to some authors who have worked to develop Lévi-Strauss's original insight, the concept of 'maison' derives its strength not so much from the success of formulating a principle of social organization capable of explaining concrete situations where neither of the two principles of kinship - descent or alliance - applied, but in his proposal to construct a relational approach that also included the physical house. This is the direction taken by the critiques and attempts to move 'beyond' found, for example, in the book About the House: Lévi-Strauss and Beyond (Carsten \& Hugh-Jones eds. 1995). According to Carsten, the merit of the formulation is its recognition of the importance of this native category and its fertility when it comes to understanding some social worlds (Carsten 1995: 225).

The critique made by Louis Marcelin in his works on black families takes the same line. Although Lévi-Strauss's 'maison' allows us to question 
the concept of household by suggesting an analytic integration of the physical house and kinship relations, it is nonetheless of little use when it comes to thinking of the social world of Bahia's Recôncavo region. One of the main questions identified in this shift away from the 'societé de maison' is Marcelin's interest in investigating "the conditions for the emergence of the house and of the social practices that both construct it and are constructed by it" (1996: 97), a question that Lévi-Strauss does not tackle. Marcelin incorporates the suggestion of "introducing the house as a physical reality and social institution into the centre of the analysis of social organization" - recognizing the significance of Lévi-Strauss's contribution - but proposes to 're-situate' the concept (ibid: 96). Hence Marcelin's use can be seen as a reformulation that proposes to deepen the basis of Lévi-Strauss's proposal while dropping its explanatory pretensions, in part because these are based on resolving a problem - the failure of a particular structural model to explain certain phenomena - that for the former does not apply.

The possibility of exploring the favelas from the viewpoint of their houses was suggested by Marcelin in a footnote to his doctoral thesis (1996) on the need to produce positive descriptions of the houses found in the poor urban peripheries. As he observes, many analyses adopt a 'miserabilistic' approach that identifies the relations between houses, families and environments depicted as anomalous, or takes the house to be the expression of the capacity to adapt to a context of deprivation. Marcelin also calls attention to a text by Klaas Woortman, 'Casa e Família Operária' [The House and the Working Class Family] (1980), one of the few texts to emphasize the importance of considering the house beyond its 'material dimension' as a 'basic need' in the specific context of favelas.

At an analytic level, therefore, I shall follow the suggestion by Marcelin, which he in turn attributes to Lévi-Strauss, namely to "place the house at the centre of the analysis," combining its physical and social aspects within a relational approach. Marcelin also suggests focusing on the genesis of the house - a question to be discussed later in this text in relation to Aliança - and on the house as a 'process,' which resonates closely with the idea of focusing on movement and transformation, in contrast to the construction of fixed discrete units in the spheres of kinship or economic practices.

Marcelin writes: 
The house is not only a transmissible individual property, a thing, a family property, an ideology. It is a practice, a strategic construction in the production of domesticity. Neither is it an isolated, self-contained entity. The house only exists in the context of a network of domestic units. It is thought and experienced in inter-relation with the other houses that participate in its construction - in the symbolic and concrete sense. (Marcelin 1999: 37)

In Marcelin's analysis, the idea of a 'configuration of houses' is inseparable from his proposal to pursue a house-based approach. The configuration is defined as the "analytic representation of an array of positions that connect networks of houses" (1999: 37), which summarizes the definition presented by Marcelin in longer form in his thesis (1996). Sometimes, however, the configuration is treated as a "set of houses structured by an ideology of family and kinship" (1999: 33), constituting a unit in itself, both discrete and empirically identifiable. It is this formulation that allows us to perceive, for instance, that a person belongs to a "configuration of two to seven houses." These two modulations of the concept of configuration are not contradictory or mutually excluding, considering Marcelin's approach, but it does suggest that this second use is specifically linked to its empirical universe. Consequently, though inspired by Marcelin's formulations, the use of the concept of configuration of houses made here should be specified clearly.

In Aliança the houses related to each other do not constitute discrete units and the relations between them are not always expressed through the language of kinship. The relations between houses can only be qualified by taking a particular house as a reference point. The places occupied by the houses in a configuration are not a quality of the configuration itself or of a house but of the position of one house in relation to others.

Therefore I choose to turn to an earlier development of the concept by Norbert Elias (1980). ${ }^{5}$ Elias's proposal is based on rejecting both methodological individualism and the reification of 'society' or the 'group' as perspectives through which one can comprehend the social world. Configuration for Elias ('Figuration' or 'Interdependenzgeflecht' in German, literally 'mesh of interdependence') is an analytic perspective that allows us to see via arrangements

5 Louis Marcelin does not refer to the concept as formulated by Elias, but explains that he makes 'the same use' as the latter author in The Society of Individuals. 
that are only intelligible through the relations between the elements composing them. It is presumed that these elements are relatively autonomous and for this reason establish diverse and mutable relations among themselves, constituting something - a configuration - that possesses a degree of intelligibility, but lacks agency. We are not dealing here with people but houses. Applying the idea of configuration to Aliança and its houses, therefore, we can define the 'configuration of houses' as a perspective that affords a more intelligible account of the multiple and diverse relations between a house and other houses, each one of them relatively autonomous but dependent on others. The house and the configuration of houses will give substance on the analytic level to what the ethnography allows to emerge through the observation of everyday practices.

The pioneering work of Marcelin has shown the productiveness of the use of the idea of house and configuration to situate the study of family in terms closer to how these relations are experienced. My adoption of this analytic proposal in order to conceptualize the elements modulating the economy of Aliança has the same purpose: to produce positive descriptions, eschewing the normative models that present themselves at various levels in relation to economy, family and favela. This allows us to comprehend who the subjects of these practices are and how objects, people and constructions are related and mutually constructed. But it is not just at an analytic level that the concept of the house will relate here kinship and economics. The proximity between the approaches goes beyond the abstract. The house enables us to qualify the forms through which the spheres of economics and kinship are intrinsically linked in everyday practices.

The relation between the houses of parents and children is the strongest in the configuration of houses. I shall show that the man's father and the woman's mother are particularly important figures in the genesis of the house and in the ties that it maintains with the houses from which they originated. Care of grandchildren also plays an important role in the exchanges between the houses. This care is seen to be extremely important in Aliança in relation to boys, given the perceived risk that "they could do something wrong." The languages of the house and kinship are used to qualify relations of proximity, affect and obligation in Aliança. Based on specific local uses, I intend to show how the language of kinship and house are used to express proximity, affect and expectations of obligation and respect. 
The centrality of food in the configuration of houses connected through Maria's house - its preparation, the place it occupies in the construction of the house and commensality - is an important link that enables economic practices to be analysed in closer proximity to the relatedness expressed by kinship ties. The relation suggested by Janet Carsten (1995) between the house, bodies (particularly the female body) and the construction of kinship through the sharing of substances via food helps reveal the interweaving of practices between the dimensions of the economy and relationality. Marshall Sahlins's (2013) definition of kinship as "mutuality of being" stresses the role of such relational aspects to the construction of kinship ties.

\section{Making a house}

The genesis of the house affords an understanding of the ways in which ties between houses are built. The asymmetry present in relations of care within the house forms the basis for the relations between the new house and those from which it originated, including moralities and mutual obligations. The ideal of autonomy is central to the construction of a house and also has to do with care and responsibilities over the behavior of youngsters.

When they married, each of Maria's two daughters received help - this is the word used - from their parents and parents-in-law to buy and improve their houses. Maria gave as a present some furniture bought with a credit card and lent a sum of money. The mother insisted that the two daughters went to live in a house on the same street as her own. The houses were less than ten metres away from each other.

One time Maria was close to home when she met José, her brother-in-law. In a teasing tone she said to him: "I heard that Márcia is already pregnant..." The girl to whom Maria referred was the girlfriend of José's son. Stunned, her brother-in-law replied: "Who told you that?" and added, now serious: "I am already making a house for them!" Some time later the couple married, before the baby was born, at a party in the bridegroom's parents' house. This was held as soon as the house being built for them was deemed ready enough to be inhabited.

The help given by the parents of a new couple towards building or buying a house can take the form of money or construction materials. This is common in Aliança and other research studies describe similar processes in 
favelas and other localities. ${ }^{6}$ A new house is the offshoot of one or two other houses and remains linked to them. It is common for young couples to continue to receive presents and financial help from the parents for a long time after. Those who are cared for (usually the children) constitute new houses with help from the parents' house, simultaneously marking the end of care and generating the possibility of themselves caring for others: their own children and in the future, for example, elderly parents or sick relatives.

When a woman becomes pregnant before constituting a house (before marrying), the parents, generally the young man's, feel obliged to "set up a house" for the new couple and even if they lack the means to sustain themselves, the parents (generally the young man's father) make every effort possible to establish a new house. Depending on the means available - such as money and land - this includes making efforts to delimit separate physical spaces and give them the concrete appearance of autonomy that a new house possesses socially.

The house is the delimitation of a space - physical whenever possible in which care is central to the asymmetry that underlies both the relations constituting the house and the relations between this new house and the house(s) of origin. A new baby must be cared for and, at the same time, creates the obligation to care. As we can see, through the value attributed to the obligation to make a new house when a child's arrival is announced, someone who cares is no longer cared for. The relation of care within a house is converted therefore into a relation - likewise asymmetric - between the houses inaugurated by the 'help' given to make the new house. Despite the fact that these two examples involve parents and children and that these tend to comprise the positions of the members of the original house and the new house respectively, what I wish to show here is that we are not dealing with a model involving obligations between parents and children: rather, what is at the base of the houses and their relations are the asymmetries defining the interdependence that constitutes them.

The ideas of each house being autonomous and the obligations and interdictions in relation to other houses involve moralities, and a substantial portion of the gossip and the construction of reputations - both good and

6 See Cavalcanti (2007) and McCallum \& Bustamente (2012).

7 I shall discuss later the material aspect of the autonomy of the houses. 
bad - occurs around them. The story of Márcia's pregnancy had already been told to me in a gossiping tone as something that sullied the reputation of the families concerned. It is considered desirable for the couple to have a house before having children. José rushed to ensure this happened. Some mothers told me proudly that their daughters had only become pregnant after obtaining their own houses.

The idea that a house should be composed of a father and mother and their children participates in the symbolic and material shaping of the house, combining the ideals of autonomy and a space of care. This native representation should not be confused with the model of the nuclear family on which normative views are based. McCallum \& Bustamente call attention to the necessary distinction between native representation and analytical essentialization, which grounds the classification of poor families as anomalous entities. On one hand we need to put aside the normative view of the family at the analytical level, while, on the other, paying attention to indigenous notions of normality and abnormality. Situations deemed shameful or to be avoided show that the principles of care, responsibility and asymmetry underlie the idea of normality and abnormality. The couple with children is the ideal modality for what is considered normal and socially acceptable. ${ }^{8}$

Lucia's house is one of the situations considered abnormal. She lived with her husband and son. When the son reached the age of 14 , or thereabouts, the father left. The boy began to attack his mother physically, demanding money and complaining about the food. He prohibits her from going out without his permission. The boy refuses to work and "brings no money home." This situation is considered a source of vexation and shame by Lucia and her neighbours. The boy is young, earns no money, and yet he exercises a role of authority that contradicts his lack of involvement in maintaining the house.

Dona Berenice is the mother of Solange, married to Nelson. When the mother went to live in Aliança, having separated from her own husband, she did not go to live in her daughter's house. Instead the daughter divided up the space that her own house occupied in order to build a house for her mother: a room with a bathroom and a small kitchen, with an entrance separate from her own. The mother could not occupy either the role of

8 McCallum and Bustamante show that the native representation of the nuclear family as 'normal' participates in the configuration of houses, allowing those recognized to belong to this category to establish relations with other houses. 
caring - the daughter is married and has her own children and grandchildren to care for - or the role of being cared for, since she is a healthy woman who earns her own income and works. The construction of a house was perceived, therefore, as a necessity. A single space - which had been occupied by Solange's original house - had to be transformed into two houses, in order to be able to develop the autonomy needed to function as a space of care.

Care also involves the responsibility of the care giver over the conduct of the care receiver. Young people who are considered to "do wrong things" - becoming involved with drug trafficking, thefts, consuming drugs - cause shame to those expected to care for them. Maria recounts that after learning that her son was working with 'the bandits' she was "unable to look the neighbours in the eye." She says that mothers in these cases "feel a great deal of shame." The bad conduct of young people can be attributed to the way in which they were 'raised,' as a failure to fulfil the responsibilities of caring. When those who care have an undeniably positive reputation in the community as 'workers,' the problem is seen to reside in a fault in the youth's own character. On the other hand, some families are famed for being a 'family of bandits,' meaning that it is seen to be only a question of time before the youths become involved in "something bad."

When they came to Rio de Janeiro, Maria and Antônio initially went to live in the house of Antônio's brother who already lived in Complexo do Alemão. During this time it was up to José to shelter his younger brother, wife and two children, sharing not only the dwelling, but also food and the work of caring for the children. The newly-arrived brother was the youngest child of the family, meaning he could momentarily assume the position of someone to be cared for and, by extension, his family too. This was a very common form of creating new houses in the favela, linked to the migration of people from other parts of Rio de Janeiro state and other regions of the country.

This way of creating new houses is related to configurations of houses that extend far beyond those built in close proximity. Many houses in Complexo do Alemão were constituted through configurations with houses in other states. One locality in particular, for example, concentrates houses that belong to configurations with a specific locality in another Brazilian state. At the end of each year the residents hire two coaches and travel to spend the holidays with their relatives from the houses in this city. 
The configuration of houses that I discuss here also include houses from the sítio (a rural smallholding) where Antônio's family live in the interior of Pernambuco. This link is represented by Maria through the relation with one house in particular: the house that the couple built when they lived in the Brazilian Northeast, 'given' to a sister of Antônio after they came to Rio de Janeiro. This is the house that Maria still treats as 'hers' and where she stays when she goes with her husband to visit his family.

Studies of migration from rural areas to the city have shown how the relation between rural houses maintain continuities with the new houses in urban areas, both in terms of their form of organization and in the relation that they maintain with the houses in their places of origin (Garcia 1975, Heredia 1979). This is the case of Maria's house, both its origin and the relation maintained with the sitio where Antônio's parents live and some of his brothers and sisters.

\section{Food exchanges and the configuration of houses}

The configuration of houses is constituted in the exchange relations occurring between them. Food - and objects related to it - is the principal element of day-to-day exchanges, making the kitchen a central space in the relation between houses. Women, as managers of the kitchen - from planning meals to preparation, organization of the space and how people eat - are the leading figures in maintaining the ties that unite houses.

What is exchanged, but also the form in which one exchanges - what is exchanged for what, the time waited before returning a loan, who delivers the objects - are aspects of the relations between the houses involving relations of trust, love and friendship, as well as distrust and conflicts.

It is common for a number of people to visit Maria's house during the day. Some of them shout at the door waiting for the reply telling them to come in. Maria's grandchildren, daughters and sons-in-law do not do this. They enter the house merely announcing their arrival in a loud voice. These people who do not wait for permission to enter are the same ones who always eat when they are there when a meal is being cooked or served. When Maria needs a particular tool or household appliance, Maria goes to her daughters' houses. She asks to borrow the fan, a cake tin, or asks for some ingredient she is missing to make a dish. Her daughters do the same. Maria's oldest 
grandson spends most of his afternoons in his grandmother's house where he makes the meals, uses the internet and sometimes has friends round to play. The youngest grandson spends the night there sometimes when he is ill. When Maria's younger daughter underwent a medical operation that limited her movements, her mother went to clean the house and make food for her, her husband and their son.

But not only the daughters, grandchildren and sons-in-law frequent Maria's house. Various women and very rarely some men also visit the house. Most of the people are considered 'friends' and they are always invited to share the meal being prepared. Maria is also always invited to eat in these people's houses. This is the case of Solange, who owns a shop nearby. The two women used to have a trailer selling snacks together. Maria gets things from Solange's shop and pays later, runs the business when Solange travels and occasionally helps her organize the stock. Solange helps Maria with her social project. When I arrive at Maria's house and she is not there, I go straight to Solange's shop where the two friends are usually chatting.

One time I arrived at Solange's shop with Maria and she was visibly upset. Maria told me that she was annoyed because of Andréa's - one of Maria's daugthers - party. After a party in Andréa's house, her mother had gone to the shop to take a piece of cake to her friend. Many times I saw Maria taking pieces of cake to the houses of other people the day after a party in celebration of her birthday or that of her husband, or in her daughters' houses when these people allegedly "had been unable to go." It is a form of them participating too in the celebrations, being included in the exchanges involved in them - the obligation to return the invitation and give a present. Solange was upset because she thought Andréa herself should have taken the cake, not her mother. She refused to eat it, telling Maria that Andréa did not like her, which was why she herself had not brought the cake.

Even though part of the configuration of houses belonging to Maria's house, Andréa and Solange do not much like each other. Andréa goes to Solange's shop and they treat each other politely. The close relation each of the women have with Maria keeps them related to each other. It is everyday acts of exchanges between the houses, like the one that occurred with the cake, that reveal the conflict between the two. As can be perceived, the objects and food do not only circulate: the forms in which they circulate are important to the configuration of houses. Solange says that the cake would 
be very welcome were Andréa herself to take it, since it would show that she 'likes' her mother's friend. Taken by Maria, the cake loses all its value as a form of including Solange in the party.

I arrived in Aliança one day and all the businesses - bars, newsstands, shops, banks and street vendors - were closed. Nothing was sold or bought in the street. It was not a holiday. The media had reported that a famous and important drug dealer had been killed the night before and there had been orders from the tráfico for none of the businesses to open anywhere in Complexo do Alemão. ${ }^{9}$ arrived at Maria's house and she had just learnt of what was happening. She had gone out to buy ingredients to make lunch and found the markets with their doors closed, the road empty and in silence. She was agitated because to make and serve our lunch she needed soft drinks and onions, at least. So went to the house of Kelly, Maria's youngest daughter, where her son-in-law and grandson were too. Maria went straight to the kitchen and searched the cupboards. She failed to find what she needed. She then went to Solange's house, where the latter's mother was visiting. She did not have what she wanted either, but Dona Berenice said that she had food and that we could eat there. Maria declined and Berenice said that Solange's husband was eating "at Leandro's." Maria gave a little cry of joy. The metal door to Leandro's snack bar was open just 50 centimetres. Maria squeezed through the opening and said: "Aha! I knew that you lot were here!" The three men who were sat at a table eating asked her to speak quietly, "because the boys are at the door on the lookout." Maria said what the needed and Leandro handed her a plastic bag with two onions. She said that she would give them back the next day and asked for a bottle of soft drink to which Leandro refused. Having solved the onion problem, Maria still needed drink to go with the lunch. She then knocked on the door of Zélia's house and her daughter answered. Maria said: "Lend me one of those fruit juices that your mother bought yesterday.” The girl brought her a packet of powdered juice. Having everything she needed, Maria returned home and began to cook. After a while Geralda appeared. She said that she needed meat to make lunch for her husband. Maria opened the freezer and said that she could lend her some chicken, because the meat she would use for her own husband, since the food

9 Prohibiting businesses from opening in their area of control is a common form used by armed groups of drug dealers to display mourning for an important leader who has just died. It is also an eloquent form of demonstrating - and reaffirming - the power over a territory after a significant loss from their ranks. 
she was making in the saucepan was for me. Geralda left satisfied with the chicken. Feeling bad because Maria was cooking the meat that should have been for her husband, I told her that she did not need to cook for me. Maria said: “Don't worry. I didn't lend her the meat because I know that she can't give back meat. Chicken... perhaps there's a chance..."

The houses related to a particular house do not all relate to it in the same way. On the day when the businesses were closed, Maria prioritized going to certain houses first and later to others, and the order of the visits followed the order of proximity that Maria perceives in relation to the houses. At the same time the 'loan' to Geralda showed that there exist differences in relation to the value that can be lent, depending on the proximity which people perceive to exist between them.

The word 'loan' utilized here in relation to things that will be consumed (onions, juice, chicken) is used in contrast to selling and giving, and is used when the person receives something for which they asked, such as a missing ingredient needed to make a meal. What the person receives will be returned through things equivalent in value and substance and in a short space of time. The types of exchange vary in relation to those who are exchanging and in relation to the situation in which the exchange takes place.

Most of the times I was with Maria she was preparing a meal. She never let me help her, except for the days when a party was being held and many people would help, including her husband. On a day-to-day basis Maria maintains strict control over the space of the kitchen and the preparation of food in her house. She decides what she is going to make and manages the ingredients so that they are sufficient and adequate to the occasions when they will be consumed. People who may be present for dinner and lunch in Maria's house include her husband, daughters, sons-in-law and grandchildren, friends and occasionally someone who is staying in the house, such as the case of two of her friends who used to live nearby but moved to distant places: their houses remain part of the configuration of houses, Maria being godmother to the son of one of the women. When the meal is ready, she first serves her husband, then the plates of other adult men (usually her sons-in-law) and any children (usually her grandchildren). Sometimes she also serves food to the daughters' plates, or they serve their own food. Finally the other women may serve themselves from the pans, with Maria serving extra to anyone she thinks was served little food because they are 'being 
polite.' Preparing a sufficient and satisfactory quantity of food is sometimes a physical effort requiring significant financial resources from Maria and has a moral value. 'Eating well' is a sign of respect and recognition vehemently sought by close observation of people's plates to see whether they were sufficiently full at the start of the meal and completely empty at the end. Finally Maria serves herself and always begins to eat after everyone else.

McCallum \& Bustamante (2012) show how activities like cooking, cleaning and caring for children are gendered and how they participate in individuation and the construction of relations between people in a house and between houses. What we can observe in Maria's kitchen is that it refers not only to a house but to other houses too. The form in which people belonging to other houses take part in meals shows that the control of a kitchen extends - no longer as a strict control or monopoly - to the relations outside the house to which it belongs.

Men also participate in the exchanges between houses by carrying out repairs to the buildings, furniture and electrical appliances. The men connected to Maria's house earn or earned money performing activities similar to those involves in these jobs: Antônio worked in civil construction, Kelly's husband is a joiner, and Andréa's is a metalworker. Taking care of aspects such as plumbing, electricity and the proper functioning of domestic appliances (washing machines, ovens, refrigerators) identifies men with the value of being a 'worker' and signals that he "cares for the family." The worker category is central in the favela and distinguishes men in relation both to 'bandits' and to men dishonoured for being lazy or dishonest.

Maria sometimes buys clothes in Solange's shop and pays later. Sometimes she takes money to pay for transport when she needs to travel outside the community. Solange sometimes gives money for the parties that Maria organizes as part of her social project. When she had a snack bar that sold meals, it was there that Maria's teenage son ate every day.

Shops and business spaces also compose configurations of houses, always attached to the main house to which the shop is related. A shop is generally linked to a house which it supplies with an income and whose members all assume responsibility for its activities in some fashion. These shops form part of the configuration to which the house belongs, both as a space of sociability and as source of resources for the exchanges. This does not imply that the shop and house are indistinguishable, a subject to which I shall return later. 


\section{House money}

In Aliança distinctions are made in the use of money. These are based on the centrality of the house and the relations it maintains to other houses through the separation of the 'house money.' Circuits of products and money are based on identifications between ways of earning and spending: so, for example, money from selling cosmetics is used to pay for similar products, money from rent is used to pay rent, and so on.

Maria sells products made by the cosmetic company Natura. The company's sales system works as follows. The person qualifies to become a 'consultant' and begins to receive magazines with the products. The clients choose the product from the magazine which shows the price. The consultant then orders the products by telephone or internet and receives them at home, delivering them to the clients later. Along with the products she receives an invoice relating to them. The price paid by the client is $30 \%$ higher than that paid by the consultant, the difference providing the earnings from the sale. The consultants have a minimum sales quota per month to guarantee their continuation as sales representatives. ${ }^{10}$

Maria earns little money from this activity, but benefits from having access to a certain type of product at a lower price than she would pay as a final consumer. One day she was showing me the products in a parcel that she had received from Natura. She told me that she had bought various things for herself and her husband, but that the value of the purchase was almost identical to the profit from the sale of the products ordered for other people (who pay the magazine price, $30 \%$ higher than the price she pays). She explained: "In the end, for all of this I am only going to pay ten reais. I'm not going to use house money to buy these things!"

The 'house money' is what ensures the payment of regular bills (in Maria's case, the internet, cable TV, telephone and gas), as well as food, cleaning products and some products of personal hygiene. Just as part of the money - which in Maria's case comes from her husband's wages - is marked as 'house money,' so the profit from the Natura sales is already earmarked for

10 Joint strategies exist among consultants who are friends to ensure that they meet the necessary monthly quota. A seller who has been unable to get enough orders will commonly ask a friend to make orders through her. In other words, the women distribute the orders in a form guaranteeing each of their quotas are met. Additionally, when there are problems with the orders or a client requests something soon after the order has been sent to Natura - which would mean having to wait until the following month to make the order - the women also turn to other friends to attend their clients. 
spending on Natura products for herself and her husband. Even if it comes from her husband's salary, this part of the money is not considered to belong to him individually. It is allocated to maintain a unit that does not serve just to maintain the life of the two residents, but is also linked to other houses whose members, for example, will make meals and consume food bought with house money."

It is between the individual receiving of the salary and its transformation into house money that we encounter one of the most serious accusations that can be levelled against a man's honour. More serious than the accusation of betrayal and adultery - tolerated by the wife and socially too in some cases $^{12}$ - is the accusation of "taking house money" to give to a lover. At the same time, various women told me, between reflecting on some aggression suffered or a prohibition on leaving the house, for example, that the fact that the husband concerned "made sure everything was provided for at home" was a motive for staying with him and in some cases obeying him. Being the provider of house money has a moral value for the majority of men and for some being the sole provider is a non-negotiable issue. A number of women told me that their husband stopped them from working. All of them said that their husband was 'jealous' and that they suspected that the money brought by their wife might have come from other men, their lovers. The distrust in relation to the sexual conduct of women is used by men as a justification for keeping them at home.

For her social project, Maria rents a space for which she pays 500 reais. Her husband earns 800 reais. Maria today does not have another source of income and the project receives no funding. This means that a sizeable portion of the couple's monthly earnings is used to keep the project going. However the money spent on renting the space for the project is paid for by money received as rent from a house that Maria and Antônio bought shortly before setting up the project. Here we can observe a separation of the money which means that the rent is paid by money from rent. Despite claiming that "it has never been so hard," the money that she receives in rent and paid for another lease is not conceived as transformable into 'house money.'

11 Flavia Dalmaso (2014) describes a similar arrangement in houses in Haiti. The money used to buy food and pay for energy and water is a specific kind, associated with the position of the couple who 'own' the house similar to the position of 'carer' in the houses of Aliança.

12 This occurs especially when the wife is considered 'sick' and unable to satisfy her husband sexually. 
Recalling the separation of the money earned from the sale of Natura products, we can identify the existence of specific circuits in which how money is earned and what is bought (or paid) with this money are related by the proximity between the objects sold and bought (not necessarily things, but services and rent, for example). As Viviana Zelizer (1994) shows, the use of money involves separations, demarcations, obligations and restrictions that distance the currency from its supposedly homogenizing function in terms of house management practices.

One Tuesday afternoon in Maria's living room, I was talking with another three women. Two of them were in their fifties while the other was less than thirty. They told me how all of them had sold knickers, clothes and jewellery, and how they had dealt with loans and paying the suppliers. They also said that the period when they were selling was also when they were better dressed, because they had money to buy "things for themselves."

Since the selling of cosmetics and underwear by consultants as a type of commerce is not connected to a specific space (a shop), women very often combine this activity with paid jobs outside the home. This trade in general is linked to women not only as sellers but also as the main buyers and to the kind of product identified with the female sphere. The money that the women earn in this form is also mostly used to buy beauty products and clothes or as savings, always with a specific use in mind: purchasing a car, improving the house or paying for plastic surgery. Using money from the sale of these products to buy similar products, or those perceived as 'women's' items, shapes distinctly female circulations of objects and money. Albeit from a different perspective to the one identified by Isabelle Guérin (2002), what we observe here is female money, not seen as secondary in the family budget, as the author shows, but belonging to a particular universe of objects.

\section{House, family and statistics}

The relation between house, family and economy is a concern of the professional of 'large numbers' to use the expression of Alain Derosières (1993), who also identifies a connection between house, money and family, especially through the notion of the 'household budget.' The IBGE (Brazilian Institute of Geography and Statistics), for example, first defines the 
'household' through its physical independence, ${ }^{13}$ and from there defines its residents - who as individuals constitute the first level in the aggregation of basic units within the IBGE Census - as members of 'household units.' The 'monthly household income' is the combined total income of the members of these household units.

The first thing to observe is that the physical construction and its independence precede the other definitions - household, family, for example - along with the supposition that each person can only belong to a single domestic unit. The census includes a series of recommendations and procedures to avoid counting the same person more than once. Physical isolation serves as the basis for defining how incomes are understood, which become related to a set of persons (reinforced by the existence of the category of 'per capita income') but only by derivation. While the house (in this case, the physical house) is a determinant factor in calculating income, in contrast to how the house is perceived in Aliança, it is its isolation that renders it intelligible. Taking into account that the IBGE uses the same criterion for its studies of family consumption, we are presented with the house as a discrete unit where no ambiguity exists on belongs among its resident and which is seen through an ideal similar to that of a company, also ideal, in which the circulation of money can be summarized on a balance sheet of incomings and outgoings.

In a United Nations document containing recommendations on censuses (UN 2007), which aims to homogenize data from demographic studies, there is one mention of the difference between the concept of 'house-keeping' and 'house-dwelling' in the definition of household units. The former takes the relation to money and the upkeep of the unit as the most significant, making it necessary to distinguish between people according to their position in the economic maintenance of the house. The latter, which was used by the IBGE in the 2010 Census, takes 'dwelling' to define the domestic unit.

According to the concept of 'house-keeping,' a household can be composed of various domestic units. In the 2000 Census this was the conception that guided the definition of the 'family,' which allowed for the existence not only of 'cohabiting families' (more than one family living in the same

13 "Domicilio [household] is the structurally separate and independent locale intended for the habitation of one or more persons, or which is being used as such. The essential criteria in this definition are those of separation and independence" (IBGE 2012). 
household), but also of figures like 'uniperson families' and 'unrelated families.' We can note, therefore, between the 2000 Census and the 2010 Census is a change in the concept used by the IBGE, switching from a 'house-keeping' model to a 'house-dwelling' model, which removed the concept of 'family' from the survey. ${ }^{14}$

What I wish to highlight here is the relevance given by professionals of large numbers to the definition of economic units based on the idea of 'household,' 'family' and 'domestic unit,' which, very different from the house that we are discussing here, is a discrete and independent unit. The understanding that can be generated from this conception necessarily distances itself from the economic practices found in universes like Aliança. This incongruence between the statistical models and the everyday economy is one of the bases for the construction of the favela as 'subnormal' and 'anomalous. ${ }^{15} \mathrm{My}$ interest here is not to show the distance between the 'reality' and the public figures, but to comprehend how the form in which they are constructed and their underlying need to construct discrete units generate spaces that are understood as anomalous. Foucault ([1977-8] 2008) helps us understand this when he shows that regulations do not reflect the desire of someone who wants things to operate precisely according to the models, but create the boundaries between what will be considered 'normal' and - in this specific case, for instance - the 'subnormal.'

\section{Houses and businesses}

Various works have demonstrated how houses as material constructions are related to domestic cycles (Fortes 1971). Cavalcanti (2007) in turn shows both the construction of a vila with various houses, related to the growth and marriage of the children, and the relation between the successive improvements made to the houses and the idea of the family's progress. McCallum \& Bustamante (2012) show the relation between pregnancy and the arrival

14 On the critiques of the model used by the IBGE in the 2000 Census, see, for example, Alves (2005), Feijó \& Valente (2003) and Saboia \& Cobo (2007).

15 The category 'subnormal agglomerate' is used by the IBGE to delimit the census sectors where favelas are generally located. According to the IBGE, the subnormal agglomerate: "Is a complex constituted by at least 51 housing units (shacks, houses, etc.), most of them lacking essential public services, occupying or having until recently occupied land owned by third parties (public or private) and generally distributed in a disordered and dense layout" (2011). 
of children and the construction of new dwelling spaces as offshoots of one woman's house. The factors identified by the authors are present in Aliança and represent various aspects of the mutability of the houses, including the possibilities for improvement and multiplication, but also the potential for transforming them into business spaces and sources of income.

The first time that Maria, in her own words, "laid her hands on her own hard-earned money" was when she decided to sell cuscuz (tapioca cake) on the beach. Maria could prepare the food at home and sometimes took her oldest daughter with her to Copacabana to help her with the sales. A friend who already did this taught her how to make the cake and some sales skills derived from her own experience of perceiving opportunities, reading the weather, and perceiving the different seasonal fluxes that lead to increases or drops in sales. ${ }^{16}$ The sale of cuscuz inaugurated a personal trajectory linked to commerce, especially of food.

Having pursued this activity for a while, Maria then began to sell within the community. After she had moved to live in Aliança, she bought icecreams and sold them at the corner of her house from an ice-filled Styrofoam container, where she would stand pitching the product in a loud voice. Soon after she began to sell cakes and sweets at the front of the house and ended up turning the room into a shop.

During my time in the field, a friend, Zélia, had transformed the small yard in front of her house into a clothing and perfume store. She worked as a caregiver for an elderly man in the house of a middle class family. She used to open the shop when she was home. The space offered the possibility of earning more money than her salary as a carer (for which she was formally employed with a signed work card), as well as allowing her to take care of the house, her children and her sick mother who lived with her. Zélia was dismissed after the elderly man she looked after died. She used the redundancy payment to train as a hairdresser. As she neared the end of the course, she became stricken with doubts about how to exercise the new activity,

16 In Rio de Janeiro the beaches are important places for businesses. There are stationary places where it is possible to buy drinks and food or rent chairs and sunshades. Another kind of commerce is undertaken by people who walk along the beach selling mostly food and drinks but also hats, bikinis and sunblock. On weekends and holidays, especially in the summer months, the most popular entertainment venues in the city are also seen as good places to make money. Besides the physical difficulty involved - walking on sand in the sun with temperatures near $40 \circ \mathrm{C}$ - the commerce on the beach, as Maria once explained, depends on a good capacity to predict the weather and people's behavior (where the trendy spots are, the proximity to paydays, major events in the city that may attract people etc). 
especially whether she should start a company with a colleague from the training course, deciding in the end to start up a business by herself. The space that had been used as a shop was transformed into a salon, therefore, where Zélia cuts and dyes hair, and offers various beauty treatments, while her teenage daughter provides a manicure service.

Leaving employment outside the home and starting to work in the commerce within the favela is a fairly common trajectory for women who have children, especially sons. Several women I knew who own shops, stalls or sell from their own houses opted for commerce in order to stay close to their male children when they reached a certain age. All the women were concerned with keeping their sons away from 'bad company' to prevent them from doing 'something wrong.' As mentioned before they referred more or less directly to the possibility of the children being recruited for services linked to the illegal drugs trade.

The fear that a son could turn into a 'bandit' is one reason why mothers decide to work near or inside their own homes, abandoning jobs and activities far from the house and with regular payment despite the disadvantages of this option, as in the case of one woman I knew, a trained teacher, who gave classes in a nearby school. Today she has a shop and told me that commerce is a ' prison with open doors,' but that she needs to keep her boy in her sights.

Here it is also important to note that women perceive the most critical moment when they need to be close to their sons to be not when they are babies or infants, but when they start to move about alone, around the age of ten. The fears in relation to daughters come a little later and are primarily related to becoming pregnant without having established their own house first.

In the cases of Maria and Zélia alike, the possibility of transforming house spaces into commercial spaces was fundamental to them being able to embark on a new activity, while also allowing the women to remain close to home. At the same time, the compensation received on being dismissed enable a large and immediate investment in a new occupation. The mutability of the constructions is one of the conditions that makes possible the simultaneous and/or successive combination of different activities to earn money, connected to strategies that involve responsibilities and possibilities relating to houses and to the configuration of houses to which they belong.

The transformation of house spaces into business spaces does not imply a mixture. Rather the houses are mutable spaces and can sometimes be 
transformed and places given over to activities other than the caring and routine life activities, such as cooking, sleeping and safeguarding ones belongings. When a house space is turned into a shop, it is effectively transformed, ceasing to be used by residents for the activities of the house. The same physical space can be accessed in a different form - for example, by people who do not have close relations with the residents or enter the house, who can, as clients, enter the place now transformed into a shop.

The house in the favela is a unit that is not defined by the physical continuity between walls or roofs in relation to what can be seen from outside. The house is defined by the place that a group of people take as a reference point for the everyday life activities, such as sleeping, eating and cooking, taking baths, storing their belongings and staying when nothing else demand attention outside. Its autonomy is defined by a door. But not all doors define singular houses. Very often, a door or alley leads to various other doors and gates until finally one arrives at a house.

It is very rare for there to be any ambiguity for residents and visitors concerning the limits between the house and the shop. This is made clear by the fact that usually people remove their footwear close to the doorway to a house but not to a shop. The shoes define which door (among the many which one may cross to reach a particular house) belongs to the house itself. Efforts are made to make this threshold as evident as possible, such as physical barriers that block entry to the house, or visual signs, such as different colours on the walls. It is common to fix curtains between the shop and the house when the spaces are not divided by walls.

Jacob Nacht (1915) showed that shoes are important symbolic elements and are especially related to power. Religious prescriptions and superstitions - as he calls them - related to shoes are common to multiple social worlds. André Dumans Guedes notes the importance of a rich vocabulary linked to the feet (2011). In a social world in which mobility is highly valued, expressions connected to everyday forms of moving about, as Guedes shows, reveal hierarchies linked to gender and wealth (and poverty). In Aliança, although feet are not part of a particularly relevant vocabulary, removing ones shoes is a central gesture in the demarcation of the spaces of the houses, linked to different forms of conceiving circulation: outside the house people walk around with footwear and inside barefoot. We can extend this observation of mobilities further by highlighting the distinction between sandals and shoes. 
Sandals are the footwear used to circulate between the nearby houses and the favela. The ease with which they are removed and put on combines with the intense circulation. Although a radical distinction cannot be made, it is more common for people to use shoes when journeying outside the favela. The types of footwear mark the moments of two forms of moving about - two mobilities - that are strongly linked to the spatial dichotomy of 'inside' and 'outside,' through which they delimit the 'favela' but also the space closer to home and those more distanced socially (rather than spatially).

\section{Selling, buying and renting houses}

The possibility of transforming constructed spaces not only relates to the transformation of house sections into shops. José told me that he managed to increase his earnings when he divided down the middle (with a wall) a large shop that he owned and was able to rent both sides for a price that, combined, was higher than the rent previously for the single shop.

Maria also divided up a house that she bought to lease. The house was large and was transformed into two homes: one with two bedrooms, a living room, bathroom and kitchen, and the other a 'kitchenette' (a space without internal walls to dividing the room from the kitchen, plus a bathroom). Again the combined rents were more than the value of the rent for the house prior to the division. Dividing up spaces is a recourse commonly used to increase the income from sales and leases of properties in the favela. Jane Guyer (2004) shows how the successive dividing up of products enables the multiplication of revenues from the same quantity of things. In a chain of successive sales, each link can benefit from the sale in increasingly smaller quantities, increasing the relative profit. In this case dividing up the buildings enables increased revenues too, but in general by multiplying the earnings from a house.

The income derived from renting out a house or shop are considered 'sure.' Maria once told me that the houses she leased were her 'pension fund.' Zélia refers to the house she rents to another family as her "guarantee that she will have something to eat." As well as being perceived as a constant source of money, ownership of the house assures what is perceived as the minimum of dignity that a person can have: "a roof over their head."

Since the initial occupation of Complexo do Alemão, people needed to ask for permission to buy or rent spaces to build (IPEA 2013). Any kind of 
transformation that may be seen to affect other houses is a motive for negotiation or even disputes between neighbours. An intense real estate market exists in Aliança and rent is an important element in the favela's economy. A perspective that is both historical and ethnographic allows us to perceive that the building and transformation of the constructions is highly regulated and constitutes a vigorous market.

The rules and contracts governing the constructions and the commercial property transactions are not registered in the ideal form presented in legislative texts and state regulations. However neither should it be thought that there is a complete divorce between them, for two reasons. First, constructions often have some kind of record with the state authorities, the result of land regularization processes, for example. Many commercial relations include at some point documents and money transfers that pass through channels regulated by state instruments. Second, the regulations, documents and state processes are commonly taken as frameworks for the practical implementation of the ordinary regulations. One example is the existence of written contracts for rentals and for buying and selling, though they are not registered with the bodies that would validate them officially.

Based on ethnographic observation of how the favela's spaces are used, therefore, we can see that not only do regulations exist, they are not opposed to state regulation, the latter being one element among others that modulate the possibilities and restrictions with which people deal when it comes to managing the use of spaces. ${ }^{17}$

\section{Houses and temporality}

The mutability of the spaces is not only central to the possibilities for earning money (whether by transforming part of the house into a shop, or by renting out the properties) but also to the form in which the past is narrated and the future imagined. This is similar to what Mariana Cavalcanti calls 'building imagination' (2007).

17 The works of Rafael Gonçalves (2012) and Claudia Franco Correa (2012) tackle the question of state regulation of dwellings in favelas. Gonçalves shows how legal treatment was historically ambiguous and enabled residents to become subject to the vicissitudes of political disputes in Rio de Janeiro and the interests of the dominant classes. Correa, for her part, is concerned with the distance between state law and rights in rem, in particular the 'right to a floor,' identifying the former as a factor in the exclusion from the right to an abode, and the latter as way of meeting this right in practice. 
Maria told me about her plans for producing savoury snacks. We were in the kitchen of her house. She showed me how she was going to block out the window that looks onto the street and put a door there instead. She would also knock down a section of the opposite wall, placing an archway connecting the new kitchen to the bedroom. She even indicated the positions of the tables and the equipment that would arrive. She predicted that Antônio would be 'fuming' when he learnt about all the changes to be made. Maria later told me that she had heard that the owner of the space rented for her social project was thinking of selling the property. She had spoken to him, and he had given his assurance that he would not remove the project from there. "But I'm not daft and I'm already thinking of what to do if he does that." She told me that she could remove the people who pay rent in the two houses she owns and knock down the wall separating them. She would move the location of the bathroom and make a small room with a table and computer. On the roof she could build a house to live in and rent out the house where she lives now. Another time Maria did the sums for me. She could sell one house for $\mathrm{R} \$ 15,000$, the kitchenette for $\mathrm{R} \$ 10,000$ and the paved floor space for $\mathrm{R} \$$ 20,000. With the money this time she would give a down payment for the space she occupies with the project and would pay the rest in instalments.

People's recollections of events in their lives are punctuated by the transformations made to their houses, and when they speak of their plans, the houses and shops are always taken as reference points, together with the possibility of transforming, selling or renting them. The constructions mark the moments of a lifetime. Everyday conversations often include evaluations of the good and bad deals people have made with their properties, the possibilities still to be exploited, the high or low prices demanded in sales and leases.

Stories about events in the more distant past are commonly narrated with constructions as a backdrop. The temporal landmarks of births and deaths (without alluding to dates) are supplemented by references to adding a room, opening a door and plastering a wall, for example, with these elements frequently being shown to the interlocutor. It is also common for the constructions and the evaluations initially linked to their material form provoke the beginning of conversations about the past that include the family and activities for spending money. Passing in front of one of the houses where Maria had lived, she began to talk about the structure of the house, the fact 
it had two storeys, three floors, the colour of the walls. Telling me about the construction, she went on to recount part of the family's history based on a temporality linked more to experience than chronological time, but always imbued with affects related to the choices made over time. The physical house, and more specifically its transformations, gave meaning to the family's history, whether temporal or affective.

One day we were leaving Maria's house when Pastor Carlos called us to see the house he was building. We went inside, myself, Maria and another friend. The two women praised the pastor's work - he himself had been working on the kitchen fittings. They commented on how the bathroom was large and the kitchen beautiful. They then began to talk about how much the pastor could charge for rent, to which he replied: "I won't charge any less than 400 !" Looking through the window Maria showed me a concrete structure still without the floor. The three of them began to calculate for how much the structure could be sold. "It's strong, very strong. It can support another two floors, easy. You could make 7 or 8 kitchenettes. Each one about 300 in rent... You could make a lot of money." When we left the house and Pastor Carlos was out of earshot, Maria and her friend chatted about how much the pastor would earn in rent from the house he had shown and the other he was building on the floor above: "The pastor is going to be rich."

One aspect to be considered about the transformations of spaces is that these are closely observed by neighbours on a daily basis. Discussing the Bela Vista favela, Mariana Cavalcanti (2007) notes that the fact that how houses are built is public knowledge, including the type of material used and the quality of the work involved, makes it an important factor in the composition of house sale prices. This factor is also present in Aliança. Moreover this everyday observation also provides elements for the house plans and strategies to be evaluated by others, feeding the reputations of good and bad workers, and those with good and bad luck. The transformations in the house or shop can be interpreted as a sign of progress or as a sign of failure when they provide the means for another activity that may have 'turned out badly.' The gaze of neighbours is always a factor taken into account, especially when people conclude that a transformation to the house may generate envy, a feeling thought capable of causing sickness and sudden ills, depending on who the onlooker is. 


\section{Moving objects and transformations inside the house}

There is another aspect to the transformation of houses, this time relating to the transformations in the organization of the objects inside it. During the time I frequented Maria's house changes were made to the decoration and the position of the furniture in all the rooms: the living room, bedrooms, kitchen and even the bathroom. Every time that I arrived to find the house different, Maria would explain to me the reasons for the changes. In each case she told me as though she herself had decided and physically moved the furniture and objects.

In her explications for the changes to the position of the furniture, it was also common for Maria to remark on how she disliked the house where she lived. She had bought the house "in desperation" when she had to leave the house that "she herself had built" after her son became involved "in something wrong." She told me several times that she felt ill at ease there. The changes seem to be linked to this dissatisfaction with what is expected from a house - that it makes the person feel good, that its purchase or construction results from free choices. When sometimes we pass in front of the house built 'by her,' Maria always tells me, nostalgically, how the house 'is good' and how she "liked living there."

Observing the transformations both to the construction itself, which allow the cultivation of plans and strategies for earning money, and to the internal disposition of the house's objects, we can perceive a connection that links a kind of object and construction - the house - to two levels of expectations, linked to future opportunities but also to the values relating to how a house should be made.

The constant work on the interior of the house became particularly intense at the end of the year when, throughout the month of December, new decorative elements were introduced and the furniture moved about. Decorating the house not only took up some of Maria's time, it also involved buying new objects, various rearrangements and was a regular topic of conversation in which she reflected on the disposition of angels, lights and the nativity scene. This is another type of transformation that expresses not an unease in relation to the house, but the effort to express positive values associated with religiosity through it. The concern over the hierarchy of symbols - the infant Jesus in the manger should stand out in relation to the other figures - and over the aesthetic value of the decoration - it should not 
be 'tacky' - reveals another aspect of the transformation of spaces linked to the expression of values. In everyday life this expression occurs through the presence of religious symbols and family photos in people's living rooms. ${ }^{18}$

\section{Conclusion}

In this text I have attempted to propose, based on the ethnographic research undertaken in a favela in Complexo do Alemão, an analysis capable of accounting for the complexity that emerges from paying attention to ordinary economic practices. In seeking out the elements that modulate Aliança's economy, we come face-to-face with practices that challenge interpretative models based on fixed boundaries between spheres of life, between houses, between objects and people, and between economy and kinship.

The concept of house has already showed to be productive in kinship and family studies by integrating its symbolic and material aspects at an analytic level. Here the house renders ordinary economic practices in the favela intelligible by showing the ways in which they interlace family practices and the transformation of spaces.This reflection maintains a critical dialogue with normativities present in the commonplace treatment of these two objects of study.

The first normativity contested here concerns what is called the 'great divide' (Dufy \& Weber 2009), a term attributed to an analytic principle, not always explicit, which provides the basis for views of the economy as a sphere separate from life, governed by rationality, calculation and self-interest. This seems to be an issue in principle resolved, given that most anthropologists explicitly reject this view in their work. However we still need to overcome more subtle manifestations of the 'great divide' paradigm, namely those that take for granted certain classifications that remain unproblematized. The risks of these 'small divides' include establishing boundaries, privileging certain spaces and practices considered a priori as 'economic objects,' and thus foreclosing the possibilities of - and need for - analyses that take into account other dimensions of social life, and analyses that lead

18 In Aliança the display of religious symbols is also important in the distinction -very often overt - between Catholic and Protestant houses. There is no space here to pursue this discussion in depth, but it involves the identification with values claimed by or attributed to one or other religion, all of which is of considerable significance in people's judgments and expectations concerning everyday conduct. 
to dialogues with other analytic viewpoints, challenging the divisions of labour within the disciplines too. The 'economy' and 'economic practices' are necessarily provisional propositions and methodological resources which enable the establishment of dialogues and a starting point, but which should be continually challenged by ethnography.

One of the premises of the 'great divide' approach which is questioned here is precisely who the subjects are when we observe economic practices. The interactions observed in Aliança reveal that these subjects do not comprise rational individuals making choices in accordance with the possibilities for larger concrete gains. A house-based approach shows that the exchanges can only be comprehended by taking into account the multiple relations in which they are involved. Choices concerning how to make a livelihood, how to spend money and so on are immersed in moralities, obligations and conceptions of the future. 'Helping' to build a house, separating 'house money,' sharing meals, making loans, all involve decisions and strategies that are unintelligible if we look for 'individuals.' Furthermore the radical separation between people and 'things,' whether these are objects, food or constructions, is also contested. In particular I have looked to highlight the diverse levels on which practices linked to food, through its movement and transformation (circulating between the houses, preparing meals), shed light on the intrinsic relation with the development of social ties. The constructions themselves, for their part, are not immobile: they are spaces that not only experience constant transformation, but whose very mutability determines both their economic value and their value as dwellings.

Another level of normativities with which we need to dialogue when studying these issues in a favela concerns the depiction - by public opinion, but also by social scientists - of these spaces as anomalous places. The anomy associated with favelas - interpreted by prejudiced and criminalizing gazes, but also by gazes that are benevolent or critical of the injustices thought to be experienced by their residents - produces a view of the favela marked by absences: of money, education, police, the state. This translates into a treatment that considers questions like money, markets, work and houses through two prisms. In one of them these absences are interpreted through the framework of 'poverty,' which takes the favelas as its main locus of expression in Brazil's urban environments, making 
it not only a given characteristic, but also a factor capable of explaining 'problems' like violence, for example. A second approach, especially present in the discourse of the professionals responsible for producing diagnoses and proposing solutions to "improve people's lives," associates these spaces with informality and illegality.

As Valladares (2005) has shown, the interpretative frame of poverty is central to the way in which favelas have been analysed historically. As the author demonstrates, at a certain moment of the production of the Social Sciences, anyone intending to study poverty conducted research in favelas and almost all research conducted in favelas was on poverty. Oscar Lewis, in his classic book on poor families in Mexico (1961), suggested that deprivations are so determinant of behaviours that one can speak of a 'culture of poverty,' which closely assimilates the poor of the city with the poor living in rural areas, and even those in different regions and countries. ${ }^{19}$

In another classic work, Larissa Lomnitz ([1975] 1981) uses the notion of 'survival' in her depiction of the population of a barriada in Mexico City which echoes Lewis's perception of a particular form of living. The similarity identified with Rio's favelas and other urban spaces in large Latin American cities forms part of the author's argument concerning the marginality - produced by the subordinate integration into modern industrial capitalism - of the people living in these places in relation to the cities and of Latin America in relation to the world. Unlike Lewis, Lomnitz takes a more integrated approach to studying this population, investigating the relation between economics, the family and networks, while simultaneously including larger scales in her analysis, highlighting the importance of migration and of relations with the city. Her analysis matches the tone of the debates in Latin America during the 1960 s and 1970s, centred on the dilemmas of a modernity that never materializes. ${ }^{20}$

From many points of view Aliança would be treated as a place of poverty. Right from the outset, however, this classification becomes problematic, analytically speaking, insofar as 'poverty' is a native and polysemic term, one

19 "Poverty becomes a dynamic factor which affects participation in the larger national culture and creates a subculture of it own. One can speak of the culture of the poor, for it has its own modalities and distinctive social and psychological consequences for its members. It seems to me that culture of poverty cuts across regional, rural-urban, and even national boundaries" (Lewis 1961:17).

20 For a critique of the 'Brazilian dilemma' strand in anthropology (the expectation of an unfulfilled modernity) focused particularly on the notion of the individual, see Pina-Cabral (2007). 
which primarily denotes a perception of difference. 'Poverty' almost always refers to people and places perceived to be socially distant. It is always 'over there.' People only refer to themselves as poor when they wish to emphasize injustices attributed to the 'government.' It is only a category that unites residents in some form when referring to a set of abstract and depersonalized entities and spatialities: 'government,' 'the police.' While on one hand the native uses of poverty suggest a problematization of the category, what the ethnography shows is that the assumptions and applications of the use of poverty as an analytic category are unsustainable.

Two factors are decisive here: the place occupied by plans and perceptions of the future, and the perception that choices exist (and indeed they do exist) to be made. The use of the notion of 'strategy' here looks to make evident both the centrality of perceptions concerning the future and the combination of choices and the perception of opportunities. The ethnographic material shows how people are very far from being conditioned by lack and, much the opposite, combine diverse aspects within their universe of possibilities in order to make a living. People in Aliança live rather than 'survive.'

The association between favela and informality is also widespread. It can be noted that the approaches vary between those focusing on the generalized informality that supposedly characterizes the favela (called the 'informal city' by some) in terms of the economy but also of housing and constructions, and those focusing on the illegal market of banned drugs. ${ }^{21}$ At the same time as being a simplifying homogenization of the favela economy, the prism of informality sets up a dichotomous distinction that takes state regulations as its parameter. These state regulations are one of the elements involved in shaping the economy of Aliança, or more precisely, they are one factor among others that compose a universe of possibilities in which people move about. Understood in this form, we can comprehend how the boundaries established by multiple regulations are manipulated in the everyday life of Aliança (Rabossi 2011, Telles da Silva \& Hirata 2007). In relation to work especially, we can perceive that there is no dichotomy between formal

21 Most of the works examining the market of illegal drugs do so through the prism of its role in the generation of 'violence.' Michel Misse draws an interesting connection between the shaping of the market of prohibited drugs and the distinct forms of criminalization to which different agents are subjected according to the perception of their potential for violence, proposing an approach that takes into account wider circuits (outside the favela) and integrates them with the circuits of "political commodities" (Misse 2002 and 2007). 
employment, small trade or temporary work, but relations between the diverse forms of earning money and between these forms and affects, plans and caring for the family.

In this universe there is no dichotomy between the principle of security associated with formal employment and the autonomy represented by running one's own business. Different forms of making money are combined simultaneously and over a lifetime. The regulations relating to work and, for example, the opportunities created by redundancy payments combine with various kinds of possibilities and constraints (the possibility of transforming a house, the need to take special care of boys) in shaping a universe of possibles.

Translated from the Portuguese by David Rodgers

Received $10^{\text {th }}$ September, 2013, approved $25^{\text {th }}$ October, 2013

\section{Bibliography}

ALVES, José Eustáquio Diniz. 2005. "A definição de família convivente do IBGE: cuidados metodológicos necessários". In: Aparte - inclusão social em debate. Disponível em:http:|/www.ie.ufrj.br/aparte/pdfs/ notametodologica_familiasconviventes.pdf

CAVALCANTI, Mariana. 2007. Of shacks, houses, and fortresses: an ethnography of favela consolidation in Rio de Janeiro. $\mathrm{PhD}$ thesis, University of Chicago.

CAVALCANTI, Mariana. 2009. "Do barraco à casa: tempo, espaço e valor(es) em uma favela consolidada". RBCS, 24(69): 69-80.

CARSTEN, Janet. 1995. "The substance of kinship and the heat of the hearth: feeding, personhood and relatedness among Malays of Pulau Langkawi”. American Ethnologist, 22(2): 223-41.

CORREA, Claudia Franco. 2012. "Direito de laje: a invisiblidade do direito fundamental de morar nas favelas cariocas". In: Marco Antônio Mello et al. (eds.), Favelas cariocas ontem e hoje. Rio de Janeiro: Garamond. pp. 313-328.

DALMASO, Flavia. 2014. Kijan moun yo ye? As pessoas, as casas e as dinâmicas familiares em Jacmel/Haiti. PhD thesis, PPGAS / Museu Nacional / UFRJ.

DESROSIÈRES, Alain. 1993. La politique des grandes nombres. Histoire de la raison statistique. Paris: Éditions la Découverte.

DUFY, Caroline \& WEBER, Florence. 2009. Mas allá de la Gran División: 
sociología, economía y etnografía. Antropofagia: Buenos Aires.

ELIAS, Norbert. 1980. Introdução à sociologia. Braga: Edições 70.

FEIJÓ, Carmem Aparecida \& VALENTE, Elvio. 2003. "Estatísticas domiciliares e políticas públicas: uma discussão sobre os conceitos de família e domicílio". Ensaios FEE, 42(2): 547-572.

FORTES, Meyer. 1971. “Introduction”. In: Jack Goody (ed.), The developmental cycle in domestic groups. Cambridge: Cambridge University Press.

FOUCAULT, Michel. 2008 [1977-8]. Segurança, território e população (Curso no Collège de France, 1977-1978). São Paulo: Martins Fontes.

GARCIA JR., Afrânio Raul. 1975. Terra de trabalho. MA Dissertation, PPGAS/ Museu Nacional/ UFRJ.

GONÇALVES. Rafael Soares. 2012. "Da política da 'contenção' à remoção: aspectos jurídicos das favelas cariocas". In: Marco Antônio Mello et al. (ed.), Favelas cariocas ontem e hoje. Rio de Janeiro: Garamond. pp. 253-277. GUEDES, André Dumans. 2011. O trecho, as mães e os papéis: movimentos e durações no norte de Goiás. PhD thesis, PPGAS/ Museu Nacional/ UFRJ.

GUÉRIN, Isabelle. 2002. "Le sexe de le la monnaie". Le Journal des Anthropologues (La dimension sociale de la monnaie), 90-91: 88-103. GUYER, Jane. 2004. Marginal gains: monetary transactions in Atlantic Africa. Chicago: The University of Chicago Press.

HEREDIA, Beatriz. 1979. A morada da vida. Rio de Janeiro: Paz e Terra.

IBGE. 2011. Censo demográfico 2010. Aglomerados subnormais. Rio de Janeiro: IBGE.

IPEA. 2010. "Intervenção sociourbanística no Complexo do Alemão". In: Brasil em desenvolvimento: Estado, planejamento e políticas públicas. Brasilia: IPEA. pp. 713-734.

IPEA. 2013. Histórico fundiário e de urbanização do Complexo do Alemão. Relatório de pesquisa. Mimeo.

LÉVI-STRAUSS, Claude. 1991. "Maison”. In: P. Bonté; M. Izard (orgs.), Dictionnaire de L'Ethnologie et de L'Anthropologie. Paris: PUF. pp. 434-436.

LEWIS, Oscar. 1961. Antropología de la pobreza. Cinco familias. Mexico: Fondo de Cultura Económica.

LOMNITZ, Larissa Adler de. 1989. Cómo sobreviven los marginados. Mexico: Editores Siglo XXI.

MARCELIN, Louis Herns. 1996. A invenção da familia afro-americana: familia, parentesco e domesticidade entre os negros do Recôncavo da Bahia, Brasil. PhD 
thesis, PPGAS/ Museu Nacional/ UFRJ.

MARCELIN, Louis Herns. 1999. "A linguagem da casa entre os negros no Recôncavo Baiano". Mana. Estudos de Antropologia Social, 5(2): 31-6o.

McCALLUM, Cecilia \& BUSTAMENTE, Sonia. 2012. "Parentesco, gênero e individuação no cotidiano da casa em um bairro popular de Salvador da Bahia”. Etnográfica,16(2): 221-246.

MISSE, Michel. 2007. "Mercados ilegais, redes de proteção e organização local do crime no Rio de Janeiro". Revista Estudos Avançados, 21(61): 139-157.

MISSE, Michel. 2002. "Rio como um bazar: a conversão da ilegalidade em mercadoria política." Insight Inteligência, 3(5): 12-16.

NACHT, Jacob. 1915. "The symbolism of the shoe with special reference to Jewish sources". The Jewish Quarterly Review, New Series, 6(1): 1-22.

NEIBURG, Federico. 2014. "Imaginary moneys and the popular economy in Haiti". American Ethnologist. (Submitted)

NEIBURG, Federico; NICAISE, Natacha; BRAUM, Pedro. 2011. Lideranças em Bel Air, Haiti. NuCEC / Viva Rio / Inured. Mimeo

PALMEIRA, Moacir. 1977. "Casa e trabalho: notas sobre as relações sociais na 'plantation' tradicional”. Contraponto, 2(2): 103-114.

PINA-CABRAL, João de. 2007. "A pessoa e o dilema brasileiro: uma perspectiva anticensurista". Novos Estudos Cebrap, 18: 95-111.

PORTER, Theodore. 1995. Trust in numbers: the persuit of objectivity in science and public life. Princeton: Princeton University Press.

RABOSSI. Fernando. 2011. "Negociações, associações e monopólios: a política da rua em Ciudad del Este (Paraguai)". Etnográfica (Lisbon),15: 83-107.

SABOIA, Ana Lucia \& COBO, Barbara. 2005. "As famílias conviventes no Censo Demográfico 2000". Paper presented to the seminar Families and Public Policies in Brazil. Associação Brasileira de Estudos Populacionais, Belo Horizonte. Mimeo.

SAHLINS, Marshall. 2013. What kinship is - and is not. Chicago: The University of Chicago Press.

TELLES DA SILVA, Vera \& HIRATA, Daniel. 2007. "Cidade e práticas urbanas: nas fronteiras incertas entre o ilegal, o informal e o ilícito". Revista Estudos Avançados, 21(61): 173-191.

UN. 2007. "Principles and recommendations for population and housing censuses: revision 1". Statistical Papers. Series M, 67(2). New York: United Nations, Department of Economic and Social Affairs, Statistics Division. 
VALLADARES, Lícia. 200o. "A gênese da favela carioca - A produção anterior às ciências

sociais.” Revista Brasileira de Ciências Sociais, 15(44): 5-34.

VALLADARES, Lícia. 2005. A invenção da favela. Do mito de origem a favela.com.

Rio de Janeiro: FGV.

WEINER, Anette. 1992. Inalienable possessions. The paradox of keeping-whilegiving. Berkeley: University of California Press.

WOORTMANN, Klaas. 1980. “Casa e família operária”. Anuário Antropológico, 80:119-150.

ZELIZER, Viviana. 1994. The social meaning of money. New York: Basic Books. 